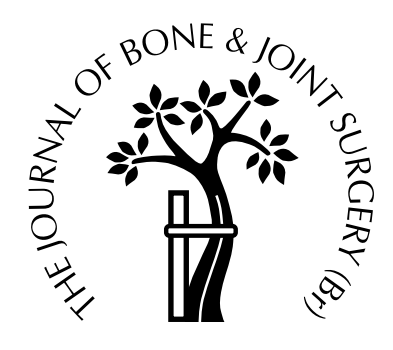

\title{
Simultaneous measurements of sagittal knee laxity with an external device and radiostereometric analysis
}

\author{
Lars P. Jorn, Thomas Fridén, Leif Ryd, Anders Lindstrand \\ From Lund University Hospital, Sweden
}

$\mathbf{W}$ e obtained simultaneous measurements of sagittal knee laxity in 12 consecutive patients after reconstruction of the anterior cruciate ligament (ACL), using the Stryker laxity tester and radiostereometric analysis (RSA).

The mean anteroposterior (AP) displacement when a $90 \mathrm{~N}$ load was applied in both directions was $5.3 \pm$ $2.7 \mathrm{~mm}$ with RSA and $9.8 \pm 1.6 \mathrm{~mm}$ with the external device $(p<0.001)$. The corresponding measurements at a load of $180 \mathrm{~N}$ were $5.7 \pm 2.4 \mathrm{~mm}$ and $13.8 \pm 3.7 \mathrm{~mm}$, respectively $(\mathrm{p}<0.001)$.

More than $50 \%$ of the sagittal knee movement, as measured by the external device at a load of $180 \mathrm{~N}$, was not true femorotibial displacement of the joint but was due to soft-tissue deformation.

J Bone Joint Surg [Br] 1998;80-B:169-72.

Received 26 March 1997; Accepted after revision 17 October 1997

Commercial devices for measuring AP laxity of the knee have been shown to be inaccurate. ${ }^{1-3}$ Soft-tissue deformation has been suggested as the reason for this error., ${ }^{4,5}$ Our aim was to evaluate the accuracy of one such device and assess the magnitude of the error during measurements in vivo. We measured the anteroposterior (AP) displacement with this appliance, and compared it with simultaneous measurement using radiostereometric analysis (RSA). ${ }^{6}$

\section{Patients and Methods}

We studied 12 consecutive patients three years after reconstruction of an anterior cruciate ligament. There were four women and eight men with a mean age at surgery of 25

L. P. Jorn, MD, Senior Registrar in Orthopaedic Surgery

T. Fridén, MD, PhD, Associate Professor, Orthopaedic Surgeon

L. Ryd, MD, PhD, Associate Professor, Orthopaedic Surgeon

A. Lindstrand, MD, PhD, Associate Professor, Orthopaedic Surgeon

Lund University Hospital, S-221 85 Lund, Sweden.

Correspondence should be sent to Dr L. P. Jorn.

(C1998 British Editorial Society of Bone and Joint Surgery 0301-620X/98/17811 \$2.00

VOL. 80-B, No. 1, JANUARY 1998 years (17 to 37). The operations had been performed through a miniarthrotomy using the central third of the patellar tendon. Four tantalum markers had been implanted in the distal femur and four in the proximal tibia. The study was approved by the Ethics Committee of Lund University Hospital.

We performed simultaneous measurements of the total AP laxity at the three-year postoperative follow-up using the Stryker system (Orthopedic System Inc, Hayward, California) and RSA. Simultaneous RSA-radiographs were obtained in the frontal and lateral projections while applying a posterior force of $90 \mathrm{~N}$ and $180 \mathrm{~N}$ as measured on the Stryker laxity tester. Radiographs were also obtained while applying an anterior force of $90 \mathrm{~N}$ and $180 \mathrm{~N}$. All measurements were made with the knee in $25 \pm 5^{\circ}$ of flexion. The marker images on all radiographs were digitised using a precision digitising table (Hasselblad Engineering Inc, Göteborg, Sweden). Movement of the tibia relative to the femur was obtained by the KINEMA routine as described by Fridén, Ryd and Lindstrand. ${ }^{7}$ We calculated the total AP displacement by each method at loads of both $90 \mathrm{~N}$ and $180 \mathrm{~N}$. The actual knee angles after application of the different loads were also obtained from the RSA calculations.

The accuracy of the RSA technique has previously been determined as $\pm 0.2 \mathrm{~mm}$. ${ }^{8}$ The precision, including biological variation (different muscle relaxation, positioning, etc), has also been calculated as $\pm 2 \mathrm{SD}$, and found to be $\pm 1.6 \mathrm{~mm}^{9}$ and $\pm 2.2 \mathrm{~mm}^{7}$ For the Stryker device the precision was found to be less than $3.2 \mathrm{~mm}^{3}$

Statistical analysis used a paired Student's $t$-test and the relationship between the results from the two testing loads and methods was expressed by Pearson's correlation coefficient (r). The 95\% confidence interval (CI) for the mean differences between the methods and the $95 \%$ limits of agreement were calculated according to the method of Bland and Altman. ${ }^{10}$ The results are given as mean values \pm SD and $\mathrm{p}$ values of less than 0.05 (two-tailed tests) were considered significant.

Results

There was no increase in measured AP movement between the RSA measurements at $90 \mathrm{~N}$ and $180 \mathrm{~N}(5.3 \pm 2.7 \mathrm{~mm}$ at 
$90 \mathrm{~N}$ and $5.7 \pm 2.4 \mathrm{~mm}$ at $180 \mathrm{~N})$. Simultaneous recordings using the external device showed increasing laxity with increasing load: $9.8 \pm 1.6 \mathrm{~mm}$ at $90 \mathrm{~N}$ and $13.8 \pm 3.7 \mathrm{~mm}$ at $180 \mathrm{~N}(\mathrm{p}<0.001$; Table I, Fig. 1). The correlation coefficient ( $r$ ) was high within each of the two methods when $90 \mathrm{~N}$ and $180 \mathrm{~N}$ loads were compared: RSA 0.92 $(\mathrm{p}<0.01)$, Stryker $0.83(\mathrm{p}<0.01)$. Between the two methods, however, no significant correlation coefficients were found: at $90 \mathrm{~N} \mathrm{r}=0.30$ and at $180 \mathrm{~N} \mathrm{r}=0.20$. The mean difference between the two methods was $4.4 \mathrm{~mm}$ at $90 \mathrm{~N}$ and $8.0 \mathrm{~mm}$ at $180 \mathrm{~N}$.

There was no clear evidence of a relationship between the individual difference between the methods (bias = systematic error) and the individual mean total AP displacement: at $90 \mathrm{~N} \mathrm{r}=-0.50$ and at $180 \mathrm{~N} \mathrm{r}=0.47$ (NS, Figs 2 and 3). The $95 \% \mathrm{CI}$ for the bias was 3 to $6 \mathrm{~mm}$ at $90 \mathrm{~N}$ and 5 to $11 \mathrm{~mm}$

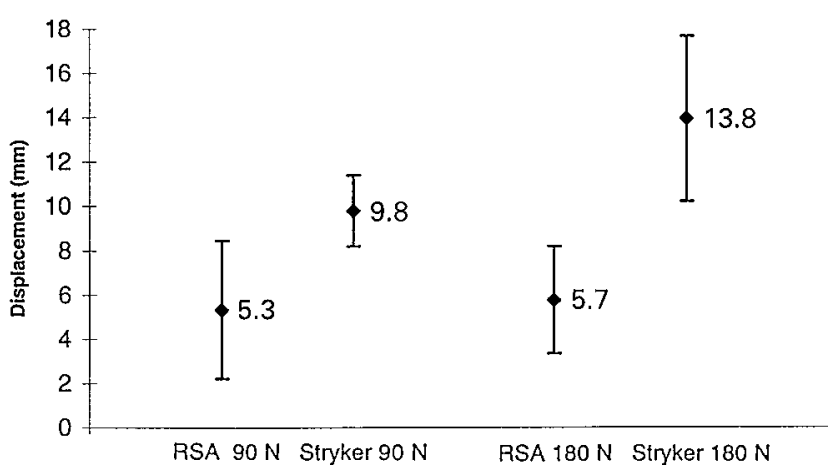

Fig. 1

Total mean $( \pm \mathrm{SD}) \mathrm{AP}$ displacement at loads of $90 \mathrm{~N}$ and $180 \mathrm{~N}$ three years after ACL reconstruction measured simultaneously by RSA and the Stryker laxity tester.

Table I. Total AP displacement ( $\mathrm{mm}$ ) and change in flexion angle (degrees) in 12 patients before surgery and three years after ACL reconstruction as measured by RSA and the Stryker laxity tester

\begin{tabular}{|c|c|c|c|c|c|c|}
\hline \multirow[b]{2}{*}{ Case } & \multicolumn{2}{|c|}{$90 \mathrm{~N}$ postop } & \multicolumn{2}{|c|}{$180 \mathrm{~N}$ postop } & \multicolumn{2}{|c|}{ Change in knee flexion } \\
\hline & RSA & Stryker & $\overline{\text { RSA }}$ & Stryker & $90 \mathrm{~N}$ & $180 \mathrm{~N}$ \\
\hline 1 & 3.6 & 7 & 3.8 & 9 & 4.7 & 9.3 \\
\hline 2 & 4.4 & 8 & 7.2 & 13 & 7.7 & 11.4 \\
\hline 3 & 3.4 & 9 & 4.9 & 10 & 13.4 & 13.5 \\
\hline 4 & 3.6 & 10 & & 12 & 11.5 & \\
\hline 5 & 6.1 & 11 & 6.8 & 16 & 7.2 & 16.9 \\
\hline 6 & 4.2 & 9 & 4.4 & 14 & 10.4 & 14.4 \\
\hline 7 & 5.1 & 8 & 5.7 & 9 & 7.4 & 12.4 \\
\hline 8 & 8.8 & 10 & & 17 & 5.9 & \\
\hline 9 & 8.8 & 12 & 7.3 & 17 & 10.9 & 20.1 \\
\hline 10 & 10.3 & 11 & 10.6 & 18 & 5.6 & 9.1 \\
\hline 11 & 0.9 & 12 & 1.8 & 20 & 9.7 & 17.5 \\
\hline 12 & 4.6 & 10 & 4.9 & 11 & 6.9 & 8.5 \\
\hline
\end{tabular}

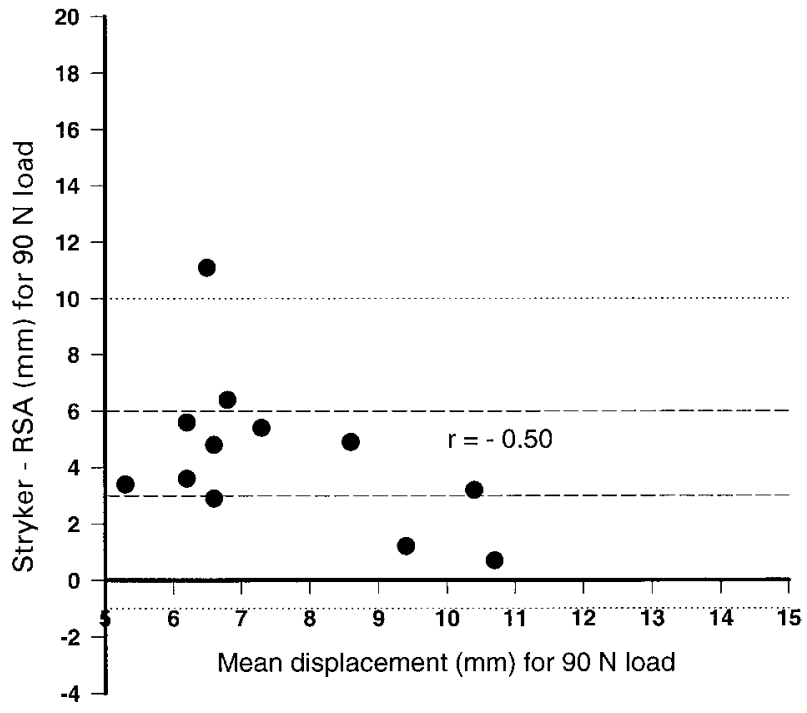

Fig. 2

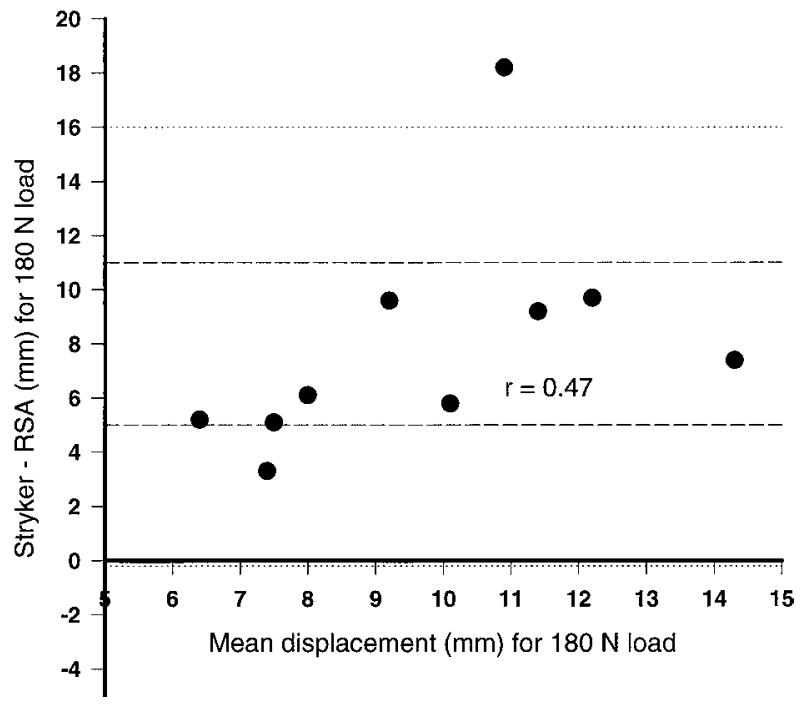

Fig. 3

Comparison of RSA and the Stryker laxity tester according to Bland and Altman ${ }^{10}$ at two different loads, $90 \mathrm{~N}$ and $180 \mathrm{~N}$, respectively (-- $95 \% \mathrm{CI}$ for the mean differences between the methods; ... 95\% limits of agreement). 
at $180 \mathrm{~N}$. The corresponding 95\% limits of agreement were -1 to $+10 \mathrm{~mm}$ at $90 \mathrm{~N}$, and 0 to $16 \mathrm{~mm}$ at $180 \mathrm{~N}$.

We found a force-induced change in knee flexion between anterior and posterior loads as measured by RSA; $8.4 \pm 2.7^{\circ}$ at $90 \mathrm{~N}$ and $13.3 \pm 3.9^{\circ}$ at $180 \mathrm{~N}$ (Table I). When this angular change was related to each individual laxity difference between RSA and the external device, $r=0.51$ (NS) at $90 \mathrm{~N}$ and $\mathrm{r}=0.62$ at $180 \mathrm{~N}(\mathrm{NS})$.

\section{Discussion}

The evaluation of different techniques for laxity measurements has mainly focused on the reproducibility of the methods. Only a few studies have determined the accuracy. Using simultaneous measurements by RSA and an external device on two specimens in vitro Edixhoven et al ${ }^{11}$ found smaller displacements on RSA. In 36 patients with torn anterior cruciate ligaments, Kärrholm et al $^{9}$ also found smaller displacements with RSA than had been earlier described for external devices. ${ }^{12,13}$ Jonsson, Kärrholm and Emqvist $^{14}$ compared RSA with the KT-1000 laxity tester (MEDMetric Corporation, San Diego, California) in 94 knees with chronic injury of the anterior cruciate ligament of which 55 had undergone ligament reconstruction. Contrary to our results, the reconstructed knees showed smaller displacements with the KT-1000 tester. The measurements were, however, not performed simultaneously and smaller loads were applied with the KT-1000 tester than for the RSA measurements; this made the comparison between the two methods inappropriate.

We have previously used RSA and measurements with external devices in a smaller group of patients. ${ }^{5}$ The measurements were not performed simultaneously and we showed significantly larger displacements with the Stryker laxity tester only when the greater force of $180 \mathrm{~N}$ was used. Shino et $\mathrm{al}^{4}$ demonstrated in vitro that soft-tissue deformation was responsible for a large proportion of the laxity measured by an external device, and Steiner et $\mathrm{al}^{3}$ found that the 'testing error' accounted for more than $50 \%$ of the measured difference in displacement between right and left knees of normal subjects. Radiological recordings of the displacement induced by passive forces have also been analysed, ${ }^{15-17}$ and the possible errors are the same as with external devices, except for the soft-tissue deformation. In addition, there are difficulties in identifying definite bony landmarks and compensating for magnification. ${ }^{17}$ To determine accurately the reliability of external devices in vivo, simultaneous measurements using RSA with implanted markers is probably the best technique. The error produced by intraindividual, repeated measurements was eliminated in the present study since the measurements were performed simultaneously, and thus errors, such as limb fixation, ${ }^{18}$ knee flexion, ${ }^{19}$ the degree of muscle relaxation, ${ }^{11,18}$ the starting position sagittally, 9,11 and the day-to-day differences ${ }^{11,20}$ were excluded by the design of the study.

The finding of a low correlation between RSA and the external device agrees with earlier studies comparing radiological methods and such machines. Stäubli and Jakob ${ }^{21}$ examined 16 patients with clinically diagnosed ACL-deficient knees by simultaneous measurements with radiography and the KT-1000 arthrometer during epidural anaesthesia. Comparisons were made at $89 \mathrm{~N}$, applied in the anterior direction. No correlation was found between the measurements obtained with the two methods.

The higher force $(180 \mathrm{~N})$ did not significantly increase the displacement as measured with RSA, and thus the RSA measurements verified a definite endpoint of joint displacement which could not be established using the external device in contrast to findings in most previous studies. ${ }^{1-3}$

The difference between RSA and the external device became greater with increasing load, and at both $90 \mathrm{~N}$ and $180 \mathrm{~N}$ the device recorded significantly larger movement than the RSA measurements of the true skeletal displacement.

RSA is mainly suitable for scientific purposes owing to the need for implanted markers. It can, however, provide us with an important technique to assess the accuracy of different external measuring devices.

We thank Mr J Ranstam, PhD, for statistical assistance. This study was supported by grants from Medicinska Forskningsrådet, Project 09509, Greta och Johans Kocks Stiftelse, Konung Gustav V's 80-årsfond, Alfred Österlunds Stiftelse, Stiftelsen för bistånd åt vanföra I Skåne, Syskonen Perssons Donations Fond, Svenska Sällskapet för Medicinsk Forskning, Thyr och Thure Stenemarks Fond, Ruth Trossbecks Minnes Fond och Albert Hellströms Fond, Centrum för Idrottsforskning, Faculty of Medicine, University of Lund.

No benefits in any form have been received or will be received from a commercial party related directly or indirectly to the subject of this article.

References

1. Andersson C, Gillquist J. Instrumented testing for evaluation of sagittal knee laxity. Clin Orthop 1990;256:178-84.

2. Anderson AF, Snyder RB, Federspiel CF, Lipscomb AB. Instrumented evaluation of knee laxity: a comparison of five arthrometers. Am J Sports Med 1992;20:135-40.

3. Steiner ME, Brown C, Zarins B, et al. Measurement of anteriorposterior displacement of the knee: a comparison of the results with instrumented devices and with clinical examination. J Bone Joint Surg [Am] 1990;72-A:1307-15.

4. Shino K, Inoue M, Horibe S, Nakamura H, Ono K. Measurement of anterior instability of the knee: a new apparatus for clinical testing. J Bone Joint Surg [Br] 1987;69-B:608-13.

5. Fridén T, Sommerlath $\mathbf{K}$, Egund $\mathbf{N}$, et al. Instability after anterior cruciate ligament rupture: measurements of sagittal laxity compared in 11 cases. Acta Orthop Scand 1992;63:593-8.

6. Selvik G. Roentgen stereophotogrammetry: a method for the study of the kinematics of the skeletal system. Acta Orthop Scand 1989; 232Suppl:1-51.

7. Fridén T, Ryd L, Lindstrand A. Laxity and graft fixation after reconstruction of the anterior cruciate ligament: a roentgen stereophotogrammetric analysis of 11 patients. Acta Orthop Scand 1992; 61:80-4.

8. Ryd L. Micromotion in knee arthroplasty: a roentgen stereophotogrammetric analysis of tibial component fixation. Acta Orthop Scand 1986;57:Suppl 220.

9. Kärrholm J, Selvik G, Elmqvist L-G, Hansson LI, Jonsson H. Three-dimensional instability of the anterior cruciate deficient knee. J Bone Joint Surg [Br] 1988;70-B:777-83.

10. Bland JM, Altman DG. Statistical methods for assessing agreement between two methods of clinical measurement. Lancet 1986; i: 307-10.

11. Edixhoven P, Huiskes R, de Graaf R, et al. Accuracy and reproducibility of instrumented knee-drawer tests. J Orthop Res 1987;5: 378-87. 
12. Daniel DM, Stone ML, Sachs R, Malcom L. Instrumented measurement of anterior knee laxity in patients with acute anterior cruciate ligament disruption. Am J Sports Med 1985;13:401-7.

13. Markolf KL, Kochan A, Amstutz HC. Measurement of knee stiffness and laxity in patients with documented absence of the anterior cruciate ligament. J Bone Joint Surg [Am] 1984;66-A:242-53.

14. Jonsson H, Kärrholm J, Elmqvist L-G. Laxity after cruciate ligament injury in 94 knees: the KT-1000 arthrometer versus roentgen stereophotogrammetry. Acta Orthop Scand 1993;64:567-70.

15. Jacobsen K. Gonylaxometry. Thesis, University of Copenhagen, Denmark. Acta Orthop Scand 1981;(Suppl 194):52.

16. Hooper GJ. Radiological assessment of anterior cruciate ligament deficiency: a new technique. J Bone Joint Surg [Br] 1986;68-B: 292-6.
17. Stäubli H-U, Noesberger B, Jakob RP. Stress radiography of the knee: cruciate ligament function studied in 138 patients. Acta Orthop Scand 1992;249:1-27.

18. Emery M, Moffroid M, Boerman JF, et al. Reliability of force/ displacement measures in a clinical device designed to measure ligamentous laxity at the knee. J Orthop Sports Phys Ther 1989: 441-7.

19. Noyes FR, Grood ES. Diagnosis of knee ligament injuries: clinical concepts. In: Feagin JA, ed. Cruciate ligaments. New York: Churchill Livingstone, 1988;10:261-85.

20. Wroble RR, Van Ginkel LA, Grood ES, Noyes FR, Shaffer BL. Repeatability of the KT-1000 arthrometer in a normal population. Am J Sports Med 1990;18:396-9.

21. Stäubli H-U, Jakob RP. Anterior knee motion analysis: measurement and simultaneous radiography. Am J Sports Med 1991;19:172-7. 